\title{
The Implementation of Duties \& Functions of Immigration Office in Granting Statement Permits Of Foreign Citizens
}

\author{
Septarina Nur Handayani ${ }^{*}$ and Sri Endah Wahyuningsih ${ }^{* *}$ \\ ${ }^{*}$ Student of Master of Law, Faculty of Law, Universitas Islam Sultan Agung, \\ Semarang, e-mail: septarinahandayani86@gmail.com \\ ${ }^{*}$ Faculty of Law, Universitas Islam Sultan Agung
}

Abstract. This study aims to determine the duties and functions of the Immigration Office in granting residence permits for foreign citizens, enforcing immigration laws against violations of residence permits for foreign nationals and knowing the obstacles and efforts made by the Immigration Office in granting residence permits for foreign citizens.

This research uses an approach method Normative juridical which refers to the applicable laws and regulations by examining secondary data against the principle of immigration law, namely Act No. 6 of 2011 as well as case studies at the immigration office.

Based on the research results, it can be concluded that the implementation of granting residence permits for foreign nationals at the Immigration Office is in accordance with the provisions stipulated in Act No.6 of 2011 concerning Immigration and related regulations as the executor. For foreign citizens who do not obey the rules, the Immigration Office can enforce the law to create state security and discipline. The obstacles faced are limited human resources, limited infrastructure, communication and administration. Efforts to overcome obstacles include: multiple assignments, procurement of generators, bringing in interpreters according to language, providing assurance of the issue of residence permits.

Keywords: Immigration; Foreign Citizens; Residence Permit; Security and Discipline.

\section{Introduction}

The mobility of people trafficking from one country to another has recently been getting busier, including the traffic of foreigners to Indonesia who have entered Indonesia for various purposes, such as travel, work or maybe even residing in Indonesia. So it is necessary to have laws and regulations that guarantee legal certainty that is in line with the respect, protection and advancement of human rights.

The entry of foreigners is expected to have a positive impact on development. As a rule of law, the government has the task of carrying out public welfare, where the state or government intervenes in taking care of the people's welfare. This becomes an absolute or inevitable in a welfare state. ${ }^{1}$

Foreigners who enter Indonesian territory are required to go through inspection by Immigration officials at the Immigration checkpoint. Immigration checkpoints are ports, airports or other places designated by the Minister of Justice as places to enter

\footnotetext{
${ }^{1}$ Iwan Sulistiyo, “Implementasi Asas Keterbukaan Dalam Proses Pembentukan Peraturan Daerah Dalam Rangka Otonomi Daerah Di Kabupaten Kendal”, in Jurnal Daulat Hukum Volume 1 No. 1 Maret 2018, p. 192, http://jurnal.unissula.ac.id/index.php/RH/article/view/2633/1982
} 
or exit Indonesian territory. ${ }^{2}$. For foreigners, services and supervision in the field of immigration are carried out based on the selective policy. Based on this principle, foreigners who can be granted entry permission to Indonesia are: ${ }^{3}$

- Foreigners who are beneficial for the welfare of the people, nation and the Republic of Indonesia.

- Does not endanger security and discipline, as well

- Not hostile to the people or the Government of the Republic of Indonesia. ${ }^{4}$

Article 2 of the Immigration Law states that every Indonesian citizen has the right to travel outside or enter Indonesian territory. In this sentence, the word "citizen" implies a juridical meaning, namely people who are members in the juridical sense of a country. ${ }^{5}$

In Act No. 6 Of 2011 concerning Immigration Article 8 paragraph (2) which states "Every foreigner who wants to enter Indonesian territory is required to have a valid and valid visa, unless otherwise stipulated under this law and international agreements". ${ }^{6}$ Furthermore, Article 48 paragraph (1) states that "Every foreigner who is in the territory of Indonesia is required to have a residence permit, a residence permit will be granted in accordance with the visa held by the foreigner." ${ }^{7}$

The Class 1 Immigration Office Semarang has the task of carrying out some of the main tasks and functions of the Ministry of Law and Human Rights in the Immigration Sector of the region concerned to carry out these tasks, the Immigration Office has the following functions:

- Carrying out Immigration duties in the field of Immigration Information and Communication Facilities

- Carry out Immigration duties in the Immigration Traffic sector

- Carry out Immigration duties in the Immigration Status field

- Carry out Immigration duties in the field of Immigration Control and Enforcement

Granting a residence permit for foreign citizens at the Class 1 Semarang Immigration Office is included in the implementation of immigration duties in the field of immigration status. The field of immigration status has a function, one of which is to determine the immigration status for foreigners who are in Indonesia. In carrying out duties and functions in the field of immigration status, it is assisted by Sub-sections, one of which is the Sub-section for determining immigration status which regulates immigration residence permits, which according to Article 48 paragraph (3) of Act No. 6 of $2011^{8}$ about Immigration consists of:

- Diplomatic residence permit

- Official residence permit

- Visit residence permit

\footnotetext{
2 Soetoprawiro, Koerniatmanto, 1994, Hukum Kewarganegaraan Dan Keimigrasian Indonesia, PT Gramedia Pustaka Utama, Jakarta, p. 75.

${ }^{3}$ Ibid, p. 76

${ }^{4}$ Ibid, p. 77

${ }^{5}$ Abdullah Sjahriful (James), 1993, Memperkenalkan Hukum Keimigrasian, Ghalia Indonesia, Jakarta, p.58.

${ }_{7}^{6}$ Act No. 6 of 2011 concerning Immigration.

${ }^{7}$ Ibid.

${ }^{8}$ Ibid.
} 
- Limited stay permit

- Permanent residence permit

In Semarang, there are several violations committed by foreign nationals, usually the abuse of visas that are not in accordance with their purpose, such as the example of a visit visa which is the basis for granting a visit residence permit whose designation is misused for work or business purposes which is carried out beyond the specified time. Another abuse is the misuse of the residence permit of a foreigner beyond the stipulated time limit, which is commonly referred to in the immigration sector as an overstay.

Based on this background, the research aims to determine and analyze the duties and functions of the Class 1 Semarang Immigration Office in the implementation of granting residence permits for foreign nationals, enforcement of immigration law carried out by the Class 1 Semarang Immigration Office against violations of residence permits for foreign nationals, as well as obstacles faced and the efforts made?

\section{Research Methods}

The approach method used in this research is a normative juridical approach. ${ }^{9}$ This research is specified as an analytical descriptive study by describing the applicable laws and regulations related to legal theory and practice of positive law implementation concerning the issue of granting residence permits for foreign nationals in the working area of the Class 1 Immigration Office in Semarang. ${ }^{10}$

The data source used in this research is secondary data, with the method of collecting data through literature study. Compiled through literature, documents and studying the provisions of laws and regulations relating to the implementation of duties and functions of the immigration office in granting residence permits for foreign citizens. In discipline to complement secondary data in the form of legal study materials, interviews were conducted with related parties in this study. The analytical method used is a qualitative method. Researchers only describe or analyze with sentences not with numbers related to the implementation of the duties and functions of the Immigration Office in granting residence permits for foreign citizens in the working area of the Class 1 Immigration Office in Semarang.

\section{Results And Discussion}

\subsection{Implementation of Duties and Functions of the Immigration Office in Granting Stay Permits for Foreign Citizens in the Work Area of the Class 1 Immigration Office in Semarang}

The duties of the Immigration Status section of the Decree of the Head of the Semarang Immigration Office Number: W9-FV.0756.KP.04.15 of 2005 which is the implementer in the service for granting residence permits for foreign nationals are to record, supervise and provide residence permits for foreign nationals who are in the area The Republic of Indonesia and grants citizenship status to foreign citizens who

\footnotetext{
${ }^{9}$ Roni Hanitjo Soemitro, 1982, Metode Penelitian Hukum dan Jurimetri, Ghalia Indonesia, Jakarta, p. 20.

${ }^{10}$ Ibid., p. 97.
} 
apply to become Indonesian citizens. In carrying out its duties, the Immigration Status section is assisted by 2 (two) Sub-Section Heads, namely the Head of the Sub-Section for Determining the Immigration Status and the Head of the Sub-Section for Reviewing the Immigration Status.

The function of the Immigration Status Section based on the Decree of the Head of the Semarang Immigration Office Number: W9-FV.0756.KP.04.15 of 2005 is to coordinate the implementation of monitoring of immigration status, empowerment of foreign citizens, immigrants and settlers and transfer of residence permit status as well as review and assessment of immigration status Foreign Citizens in discipline to carry out their duties in an disciplinely manner in accordance with the prevailing laws and regulations in the Class 1 Semarang Immigration Office area in discipline to be able to serve excellence in resolving the immigration status of Foreign Citizens and assisting the Head of the Class 1 Semarang Immigration Office in carrying out immigration duties in the field of status immigration for foreign nationals.

Coordination of the implementation of immigration status can be in the form of supervision of foreigners who involve other agencies or agencies such as the Manpower Office, Ministry of Foreign Affairs, Police, Ministry of National Education and so on. In accordance with Article 21 of Government Regulation No. 31/1994 concerning Foreigner Supervision and Immigration Actions, a Foreigner Supervision Coordinating Team (TIM PORA) was formed, and the PORA TEAM works by providing information to each other according to their respective fields, so that it can be determined coordinatively. are there any irregularities committed by foreigners and actions to be taken in accordance with their respective fields and related agencies, either individually or collectively in accordance with applicable regulations. Supervision is carried out by: checking the completeness of requirements,

The granting of a residence permit carried out by the Class 1 Immigration Semarang, based on the prevailing laws and regulations, the provisions relating to residence permits and technical procedures in granting a residence permit have been regulated in the Regulation of the Minister of Law and Human Rights of the Republic of Indonesia Number 27 of 2014 concerning Technical Procedures for Granting, Extension, Refusal, Cancellation and Termination of Visit Stay Permits, Limited Stay Permits, and Permanent Stay Permits and Exemptions from the Obligation to Have a Stay Permit.

\subsection{Law Enforcement Against Violation of Foreign Citizens' Residence Permits}

Law enforcement is a process that turns the wishes of the law into reality. What is referred to as legal desire here is none other than the thoughts of the legislative body formulated in the legal regulations. ${ }^{11}$ Improving the legal culture, among others, through education and dissemination of various laws and regulations as well as exemplary behavior of state administrators in complying with the law. ${ }^{12}$

In the framework of law enforcement as well as maintaining legal authority, as a follow-up to supervision. The implementation of prosecution for immigration violations can be divided into 2 types, namely:

\footnotetext{
${ }^{11}$ Rahardjo P, 2009, Ortodonti Dasar, Airlangga University Press, Surabaya, p.24.

12 Achmad Budi Waskito. "Implementasi Sistem Peradilan Pidana Dalam Perspektif Integrasi", Jurnal Daulat Hukum, Vol.1.No.1 (2018). url: http://jurnal.unissula.ac.id/index.php/RH/article/view/2648
} 
- Immigration measures in administrative form

- Immigration measures in the form of court proceedings ${ }^{13}$

Types of Immigration Administrative Measures, according to Article 75 paragraph (2) of Act No. 6 Of 2011 concerning Immigration can be: ${ }^{14}$

- Inclusion in the Prevention or Determination list

- Restriction, change or cancellation of residence permit

- It is prohibited to be in one or several certain places in the Indonesian Territory

- The requirement to reside in a certain place in the Indonesian Territory

- Charging of expenses

- Deportation from Indonesian territory ${ }^{15}$

The reasons for implementing immigration administrative measures according to the Immigration Law are determined as follows:

- Conducting activities that are dangerous or should be suspected of being dangerous to public security and discipline.

- Not respecting or complying with the prevailing laws and regulations.

Failure to comply with laws and regulations that apply to foreign citizens who are suspected or reasonably suspected of committing violations in the articles of the criminal provisions of Act No. 6 of 2011 concerning Immigration Articles 113 to 136.

In 2017 the immigration administrative action at the Semarang Immigration Office, it was noted that there were several violations committed by foreign nationals in the working area of the Class 1 Semarang Immigration Office. The most frequent violations are found in Article 75 paragraph (1) and Article 78 paragraph (2) and / or paragraph (3); and law enforcement committed against violations committed by applicants for a residence permit, especially violations of Article 75 paragraph (1) in the form of immigration administrative actions against foreigners who are in Indonesian territory who carry out dangerous activities and are reasonably suspected of endangering public security and discipline or disrespect. The failing to comply with statutory regulations subject to immigration administrative action by the Class 1 Semarang Immigration Office. And Article 78 paragraph (2) and / or paragraph (3) which states that foreigners who do not pay expenses are subject to immigration administrative measures in the form of deportation and deterrence. And or foreigners holding a residence permit whose validity period has expired and is still in the Indonesian Territory more than 60 days from the deadline of the residence permit, are subject to immigration administrative measures in the form of deportation and deterrence.

\subsection{Barriers and Efforts}

The obstacles in the process of granting residence permits for foreign nationals include:

- Communication

In general, the submission of the application shows that the granting of a residence permit is not very meaningful as long as the applicant complies with the rules that

\footnotetext{
${ }^{13}$ Sihar Sihombing, 2006, Hukum Imigrasi Dalam Hukum Indonesia, Nuansa Aulia, Bandung, p. 65

${ }^{14}$ Act No. 6 of 2011, Op.Cit.

${ }^{15}$ Ibid.
} 
have been informed through various media. It's just that the communication that the applicant builds with the officers sometimes does not have the same understanding with each language. The limitation of immigration officers in using foreign languages when carrying out services is very disturbing and causes misunderstanding and raises many reasons so that the service takes longer.

- Administration

Granting a residence permit for applicants for foreign nationals does not just come out easily. There are several things listed in the SOP that are sometimes difficult to fulfill by the applicant, such as the time needed to research files from one officer to another in charge. Limited Human Resources

The Presidential Moratorium on Employee Admission Limitation affects the number of HR of the Class 1 Semarang Immigration Office in service to the applicant.

- Limited infrastructure

Supporting infrastructure in the form of generators as a backup if the electricity goes out to temporarily replace the electricity function during the operation of granting residence permits for foreign nationals.

Efforts to overcome these obstacles are:

- The alternative chosen in overcoming the failure of communication between the officer and the applicant applying for a residence permit is done by asking the applicant to bring an interpreter according to their language.

- Administrative services will be faster if the fulfillment of the residence permit application file requirements is complete before being submitted. The application of SOPs in the implementation of activities must be enforced in discipline to reduce complaints from applicants.

- Human resource limitations can be overcome by duplicating the tasks associated with a person without waiting for a different officer to handle the job. This is done with the note that officers are prepared through Bintek organized by local agencies so that the concurrent tasks in the process until completion are not delayed and can make it easier for the applicants.

- Procurement of generator facilities according to the capacity needed to meet the backup needs of electrical energy providers as a substitute in case of a power cut

\section{Clossing}

\subsection{Conclusion}

Implementation of duties and functions of the Class 1 Semarang Immigration Office in granting residence permits for foreign nationals in terms of administering the application for a residence permit for foreign citizens in accordance with statutory provisions and fully carried out by the Immigration Office Class 1 Semarang through the Immigration Status Section which oversees the Determination Sub-Section and the Review Sub-Section. Immigration law enforcement carried out by the Class 1 Semarang Immigration Office, in general during 2017 against violations committed in accordance with Act No. 6 of 2011 Article 75 paragraph (1) which contains administrative immigration actions against foreigners who are in Indonesian territory who carry out dangerous activities and are reasonably suspected of endangering security and public 
discipline or not. respect or disobey laws and regulations. Likewise, foreigners who do not pay expenses are subject to immigration administrative measures in the form of deportation and deterrence. Foreigners holding a residence permit whose validity period has expired and are still in the Indonesian Territory more than 60 days from the deadline of the residence permit are subject to immigration administrative measures in the form of deportation and cancellations. The obstacles faced by the Class 1 Immigration Office in Semarang in granting a residence permit are several factors, namely, factors of communication, administration, and human resources factors as well as the provision of infrastructure. And the most dominant factor is the provision of Generator infrastructure as a backup / anticipation in case of a power cut, while in operation it is highly dependent on the use of electricity. Efforts are being made to procure generator sets to meet the need for backup electricity providers as a substitute in the event of a power cut. And the most dominant factor is the provision of Generator infrastructure as a backup / anticipation in case of a power cut, while in operation it is highly dependent on the use of electricity. Efforts are being made to procure generator sets to meet the need for backup electricity providers as a substitute in the event of a power cut. And the most dominant factor is the provision of Generator infrastructure as a backup / anticipation in case of a power cut, while in operation it is highly dependent on the use of electricity. Efforts are being made to procure generator sets to meet the backup needs of electrical energy providers as a substitute in the event of a power cut.

\subsection{Suggestion}

Immigration officers should master the duties and authorities, as well as foreign languages to make it easier to carry out their duties. There is continuous coordination between immigration officers, police and other government officials to improve the immigration law enforcement process.

\section{References}

\section{Journals}

Achmad Budi Waskito, "Implementasi Sistem Peradilan Pidana Dalam Perspektif Integrasi", Jurnal Daulat Hukum, Vol. 1 No. 1 (2018). url : http://jurnal.unissula.ac.id/index.php/RH/article/view/2648

Iwan Sulistiyo, "Implementasi Asas Keterbukaan Dalam Proses Pembentukan Peraturan Daerah Dalam Rangka Otonomi Daerah Di Kabupaten Kendal", in Jurnal Daulat Hukum Volume 1 No. 1 Maret 2018, p. 192, http://jurnal.unissula.ac.id/index.php/RH/article/view/2633/1982

\section{Books}

Abdullah Sjahriful (James) 1993, Memperkenalkan Hukum Keimigrasian, Ghalia Indonesia, Jakarta

Rahardjo P, 2009, Ortodonti Dasar, Airlangga University Press, Surabaya

Soetoprawiro, Koerniatmanto, 1994, Hukum Kewarganegaraan Dan Keimigrasian Indonesia, PT Gramedia Pustaka Utama, Jakarta 
Roni Hanitjo Soemitro, 1982, Metode Penelitian Hukum dan Jurimetri, Ghalia Indonesia, Jakarta

Sihar Sihombing, 2006, Hukum Imigrasi Dalam Hukum Indonesia, Nuansa Aulia,

\section{Regulations}

The 1945 Constitution of the Republic of Indonesia.

Act No. 6 of 2011 concerning Immigration.

Act No. 12 of 2006 concerning Citizenship of the Republic of Indonesia.

Government Regulation Number 31 of 2013 concerning Implementing Regulations of Act No. 6 of 2011 concerning Immigration.

Government Regulation Number 38 of 2005 concerning Visas, Entry Permits and Immigration Permits

Regulation of the Minister of Law and Human Rights of the Republic of Indonesia Number 27 of 2014 concerning Technical Procedures for Granting, Extending, Rejection, Cancellation and Termination of Permanent Stay Permits and Exemptions from Obligations to Have a Stay Permit.

Implementation Guidelines for the Director General of Immigration Number F338.IL.01.10 of 1995 concerning Procedures for Supervision of Foreigners.

Decree of the Head of the Semarang Immigration Office Number: W9FV.0756.KP.04.15 of 2005 concerning the description of the tasks of work units within the Semarang City Immigration Office. 